Article

\title{
Internal Corporate Social Responsibility for Sustainability
}

\author{
M. Isabel Sánchez-Hernández ${ }^{1, * \mathbb{D}}$, Jose Luis Vázquez-Burguete ${ }^{2}$, Maria P. García-Miguélez ${ }^{2}$ and \\ Ana Lanero-Carrizo ${ }^{2}$ \\ 1 Faculty of Economics and Business Sciences, University of Extremadura, 06006 Badajoz, Spain \\ 2 Faculty of Economics and Business Sciences, University of León, 24071 León, Spain; \\ jlvazb@unileon.es (J.L.V.-B.); mpgarm@unileon.es (M.P.G.-M.); alanc@unileon.es (A.L.-C.) \\ * Correspondence: isanchez@unex.es
}

Citation: Sánchez-Hernández, M.I.;

Vázquez-Burguete, J.L.;

García-Miguélez, M.P.; Lanero-Carrizo,

A. Internal Corporate Social

Responsibility for Sustainability.

Sustainability 2021, 13, 7920. https:/ /

doi.org/10.3390/su13147920

Academic Editors: Marc A. Rosen

and Ioannis Nikolaou

Received: 27 May 2021

Accepted: 9 July 2021

Published: 15 July 2021

Publisher's Note: MDPI stays neutral with regard to jurisdictional claims in published maps and institutional affiliations.

Copyright: (c) 2021 by the authors. Licensee MDPI, Basel, Switzerland. This article is an open access article distributed under the terms and conditions of the Creative Commons Attribution (CC BY) license (https:// creativecommons.org/licenses/by/ $4.0 /)$.

\begin{abstract}
The recent attention paid to internal corporate social responsibility (ICSR) observed in the academic literature has been paralleled by an increased focus thereof in management, to achieve the United Nations (UN) Sustainable Development Goals (SDGs). A bibliometric examination of the literature on ICSR and a complementary content analysis with ATLAS.ti revealed that the topic was largely neglected until 2014 but has now reached a consolidation stage. The main contribution of this paper was to conceptualize ICSR within the current theoretical paradigm of sustainability. The obtained results demonstrate that sustainable management requires attention to internal practices such as employee well-being and engagement. We anticipate that very soon, organizations will be directly involved in the SDG agenda through ICSR.
\end{abstract}

Keywords: internal corporate social responsibility; corporate social responsibility; employees; internal stakeholders; sustainability; sustainable management; sustainable development

\section{Introduction}

Sustainable development is an overarching paradigm of the United Nations (UN). It was defined in the 1987 Brundtland Commission Report as "development that meets the needs of the present without compromising the ability of future generations to meet their own needs" ([1] p. 43). To properly fulfill the core objective of sustainability, the UN defined an agenda including a set of 17 Sustainable Development Goals (SDGs) to be achieved by 2030 [2].

Furthermore, sustainable development has often been (and still is) represented by the Triple Bottom Line proposal suggested by Elkington in 1997 about corporate social responsibility (CSR) practices, i.e., the simultaneous consideration of the environment, society and the economy, and achieving a balanced integration of these three elements [3]. Based on this assumption, the managerial paradigm for the $20^{\text {th }}$ century has become sustainable management and business, with a clear vision for the future, where issues of the triple bottom line are expected to be interdependent when stakeholders are engaged.

Adapting to the new situation, nowadays, more and more companies and institutions claim to be committed to sustainability, a multidisciplinary concept comprising social, environmental, and economic issues, and involving both internal and external dimensions [4]. However, even though sustainable management implies the application of internal and external practices that contribute to sustainable development, most sustainable policies and actions are exclusively aimed at external target audiences.

The situation is similar in the academic literature. While external practices have been widely studied, internal practices have not, and evidence of the incorporation of sustainable and responsible principles in internal management practices is not particularly common $[5,6]$, even though there is evidence showing that the most effective external actions are supported by prior commitment among employees to sustainability [7,8]. As such, it may be concluded that there is still much to be done [9-13]. However, there is an 
emerging assumption in academia that sustainable development can be achieved only when attention is balanced among three complementary dimensions: societal, organizational, and individual. In this respect, different authors $[14,15]$ have proposed the concurrent consideration of CSR, HRM, and ethics to achieve sustainability. In this context, a new concept of ICSR is emerging, namely socially responsible behavior by a company towards its employees [16,17]. On this basis, this paper aims to explore the role of internal corporate social responsibility (ICSR) on sustainability, and lay the foundations for future research on this topic. The intended purpose was two-fold: first, we examine how the concept of ICSR has emerged and developed within the fields of CSR and Human Resources Management (HRM); second, we address the question of which SDGs could benefit most from an ICSR approach in an attempt to guide future research and practical applications in companies.

This study contributes to scientific advancement in several ways. Firstly, it reviews the link between CSR and HRM, and consolidates the term ICSR, also providing an updated literature review on the subject. Secondly, it allows us to clarify theoretical approaches with which to characterize the current paradigm connecting ICSR to sustainability. Thirdly, the results also suggest topics for more in-depth future research.

In the next section, we describe the research methodology, while the obtained findings are summarized in Section 3. We finally discuss the results and draw the main conclusions from our research, suggesting lines of future research.

\section{Materials and Methods}

Applying a qualitative approach, this paper provides an overview of the conceptualization of ICSR and its relevance in achieving sustainability. A general literature review was performed to shed light upon the prevailing theoretical background and the main links between CSR and HRM as antecedents of the current sustainability paradigm. First, we undertook a bibliometric analysis to assess relevant publications. Then, to understand research trends, we performed a thematic content analysis of selected publications using the ATLAS.ti software. Our study differs from traditional narrative reviews in its use of a scientific and transparent process to minimize bias.

The Web of Science (WoS) database was used, given that it includes the most relevant, impactful, and updated peer-reviewed academic contributions [18].

Specifically, by limiting the search in the WoS through the specific keywords, i.e., "CSR" and "employee" (singular and plural) in the topic (including titles, abstracts, or keywords), a total of 1378 publications were identified. In addition, by limiting the search in the same database through the keywords "CSR" and "HRM", 94 publications were found. The search was then limited to the specific keywords "ICSR" or "ISR", and the search vector (SV) was SV = ("ICSR" OR "internal CSR" OR "internal corporate social responsibility" OR "internal SR" OR "internal social responsibility"). Only 33 publications were found that conceptualized ICSR. Figure 1 shows the search process to be transparent, auditable, and replicable [19]. 


\section{STEP 1 - Theme definition, objective, research method \& search vector}

\section{STEP 2 - Search of articles in the Web of Science}

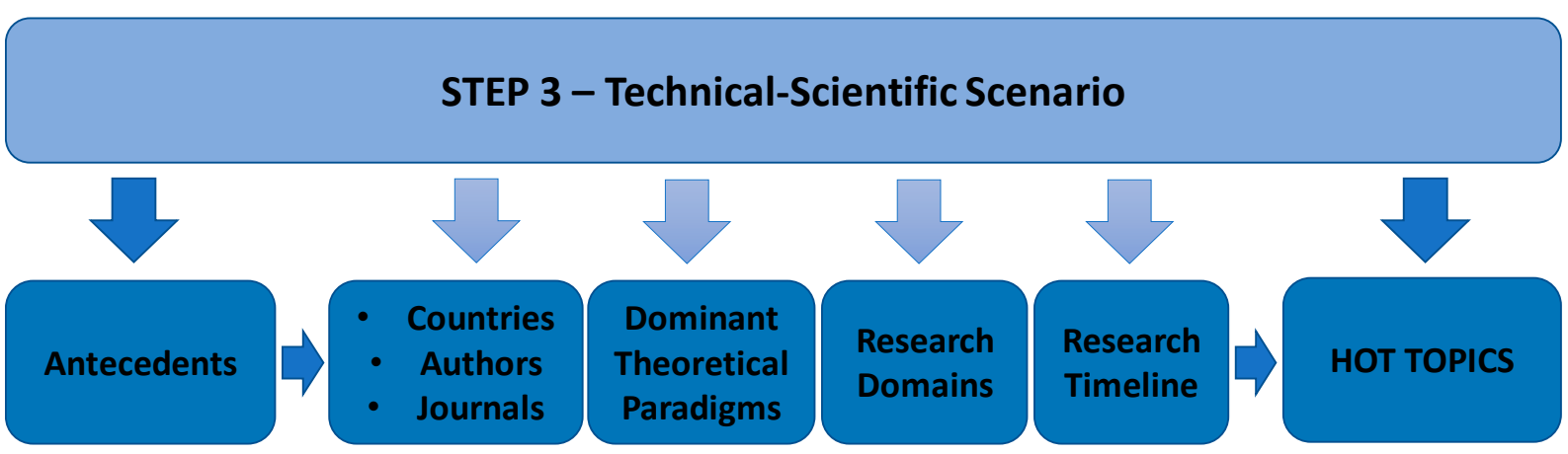

Figure 1. The methodological flow of the research.

\section{Results}

The findings obtained reveal that research linking HRM and CSR has recently increased exponentially from year to year, thus reflecting the importance of employee-focused analyses as a trending topic for sustainable management. The term ICSR has begun to gain adequate recognition as of 2014, and the growth in the number of published contributions has also been exponential since then, thus gaining strength as a strategic tool to achieve the SDGs, as it will be shown in the following subsections.

\subsection{Antecedents}

The results obtained from a review of previous research publications in the literature on employee-centered social responsibility are presented in Figure 2, which shows how publications about employee-centered social responsibility included in the WoS database are distributed over time from 2008 to 2020. In this graph, we can also see that 2014 is the concrete moment when the term ICSR began to be a relevant reference in the field.

However, concrete and relevant contributions before 2014 must be highlighted, even when their authors do indeed not name ICSR as such a concept. This is the case of the co-authored paper by Aguinis and Glavas in 2012 [20], who focused their attention on the micro-level—or the individual level—of CSR analysis. Both before and after this one, other pioneer contributions, such as those by Turban and Greening in 1996 [21], or by Lee et al. in 2013 [22], defended the benefits of ICSR for current employees by boosting their morale and engagement, as well as in terms of attracting potential employees, all with a positive impact on companies as a whole by enhancing their corporate reputation and productivity.

The systematic review of the relationship and potential linkage between CSR and HRM that was developed by Voegtlin and Greenwood in 2016 [23] recognized the novelty and originality of this research field, characterized by fragmentation, as a result of multiple contributions from different disciplines, areas, and theoretical frameworks. As of 2014, the role of ICSR began to be recognized through contributions that investigated the evolution of CSR and the inclusion of employees as internal stakeholders [24]. In the following subsections, we showed the development of recent research on the ICSR topic. 


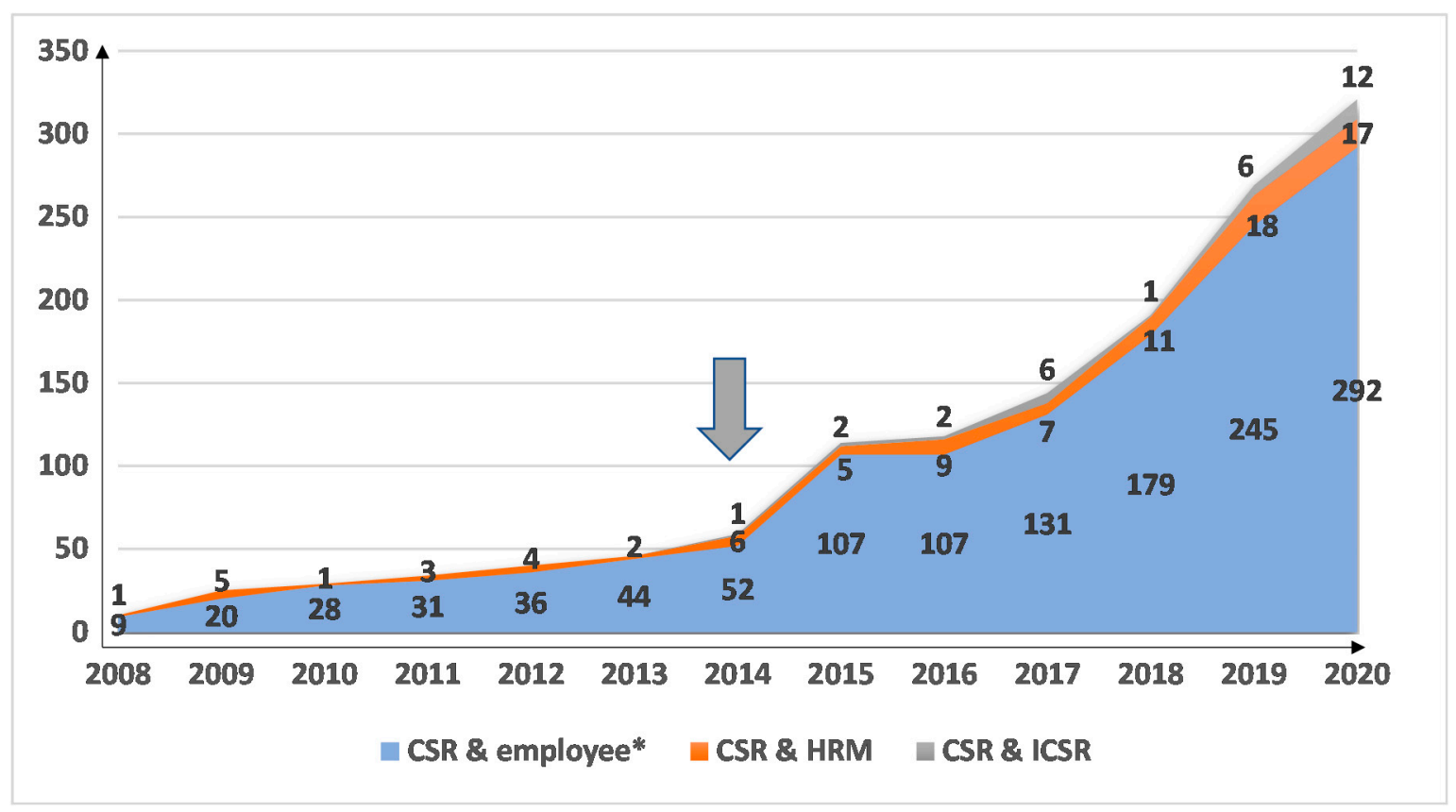

Figure 2. Evolution of the number of publications about employee-centered social responsibility in the WoS database, according to the year of publication and specific topic addressed (2008-2020).

\subsection{Scientific Analysis of Countries, Top Authors, and Journals}

Even though China and Spain are leading the ICSR study, researchers from other countries from the five continents are beginning to take an interest in this topic (Figure 3). In this sense, we did not observe a concentration of contributions (neither in terms of specific authors nor specific journals), except in the case of Mei Peng Low, from Malaysia, who could be considered the top author at this time [24,25]. Additionally, noteworthy is the broad spectrum of journals that publish papers devoted to ICSR, which demonstrates the multidisciplinary nature of the research area but, at the same time, the application of a common conceptual framework dominated by management, social responsibility, and labor relations.
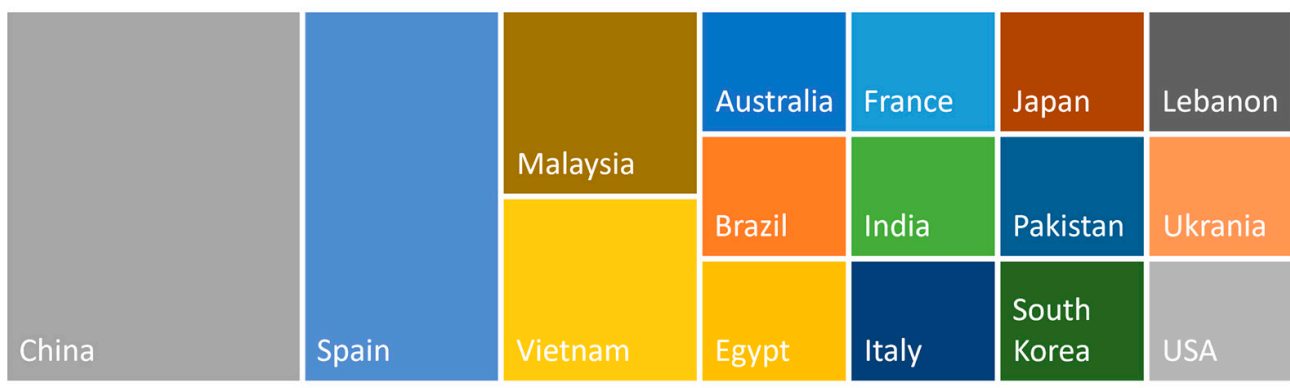

Figure 3. Analysis of contributions by country.

\subsection{Dominant Theoretical Paradigms in Academic Contributions Discussing ICSR}

Various theoretical frameworks support the link between ICSR and sustainability and different approaches have also been used to argue for the role of HRM in achieving the UN SDGs. Specifically, after having reviewed the publications on ICSR, two major complementary frameworks were found: on the one hand, the one corresponding to the perspective of social psychology, focused on employee engagement and intrapreneurship as mediators of sustainable development; on the other hand, the sustainable paradigm, 
which goes ahead and focuses attention on ethical management to achieve organizational sustainability.

\subsubsection{Social Psychology Background}

The social identity theory (SIT) is a social psychological analysis of the role of selfconception in group processes and membership rooted in the thinking of authors such as Tajfel [26] or Turner and Oakes [27]. SIT has been based on the premise that individuals define their self-conception concerning social groups, thus resulting in an identification with the collective identity [28]. On CSR, and following Mael and Ashforth [29], employees will strengthen their self-esteem and increase their self-image by identifying with the activities of their organization, such as responsible actions, both internal and external. Much more recently, different authors have mentioned SIT as one of the main theories that explain how social responsibility influences attitudes at work [30-32].

Connected to the SIT, and also rooted in the field of Social Psychology, the Social Exchange Theory (SET) [33-35] is a theoretical orientation based on utilitarianism and behaviorism as a philosophical background. In the organizational context, SET focuses on the interdependence between the organization and its employees. Beyond that, the revisited social information processing theory (SIPT) [36] has been classically postulated as a description of how mental operations affect human behavior when responding to social situations [37], thus helping to reinforce the SIT in the employee-company relationship [34]. Currently, the SIPT also considers the nature of latent mental structures, such as work models, suggesting that employees learn appropriate behaviors when HRM policies in the company are responsible [38].

In the discussion about ICSR, the identification between employees and their company is constituted as a relationship process that must be very well managed. Employees must not only be loyal, but they must also be committed and feel a close connection to their workplace, positively promote the company, and even stand up for it if someone criticizes it. In this regard, there are studies [39] that have found empirical evidence of a sequential relationship between ethical leadership as an antecedent, ICSR as a mediator, and organizational engagement as a dependent variable. Based on the same theoretical background, recent research [40] has shown how ICSR increases employee advocacy behavior mediated by employee engagement through the social exchange relationship between the company and its staff. In the same sense and reinforced by the signaling theory [41], other authors have argued that employees will correspond to the ICSR of their companies with positive behavioral responses in a virtuous cycle [42] or defending the well-being of employees, and demonstrated the relationship between ICSR and performance in a specific and important sector such as the pharmaceutical industry, through the intrapreneurial behavior of employees [43].

\subsubsection{From the Agency Theory and the Stakeholder Theory to the Sustainable Paradigm}

The classic agency theory (AT) holds that managerial behavior is closely linked to the interests of shareholders [44]. However, as society has evolved and is immersed in a dynamic of permanent change, different stakeholders raise their demands for CSR and the sustainability of companies. The stakeholder theory (ST) $[45,46]$ emphasizes that any organization should consider the interests of its shareholders (macro-level) but also the interests of multiple stakeholders (individual or group).

Following Perrini [47], there are eight stakeholder-based categories and one of them is that of human resources, with employees being the interest group. In this micro-level analysis, the interconnection between workplace social responsibility and psychological sustainability was described [48], which is directly related to organizational sustainability. Other contributions have focused on employees as internal stakeholders awaiting ICSR actions [49], and some authors have also referred to the self-determination theory (SDT) as an explanation of work motivation [50]. To analyze the relationship between the technological implementation intentions of companies and the motivation of employees, the consider- 
ation of ethical challenges in the area of cost management has been found as extremely important, such as possible layoffs due to downsizing or rightsizing. Therefore, ICSR seems to be more necessary than ever to manage job insecurity and employee motivation.

The ICSR perspective is part of the sustainable paradigm considering that purposedriven organizations must take a closer look at the internal dimension of sustainability [49]. It has also been suggested that incorporating internal sustainability dimensions into corporate strategy would enable competitive advantages and create sustainability value [50]. Moreover, organizations will positively contribute to SDGs by addressing the value of social performance through the development of relationships with stakeholders, which implies including all stakeholders in the development of the SDGs, and specifically, involving employees in decision processes.

\subsection{Research Domains}

As stated above, contributions to the academic literature on CSR and/or sustainability have mainly focused on the consideration of their external issues or dimensions of the concept. Intending to deepen our understanding of this fact, Voegtlin and Greenwood [22] carried out a systematic review of the academic literature linking CSR and HRM published before December 2014. According to these authors, three phases or stages could be identified in this evolution: incubation (up to 2002), incremental growth (from 2003 to 2008), and substantial growth (from 2009).

Acknowledging these phases, but specifically focusing on the concrete term ICSR, the first publication included in the WoS appeared in 2014. Thus, we can assume that the presence of publications in the academic literature before this time and containing the term ICSR can be considered to have had little impact, as they are not included in this database. Consequently, our updated analysis focuses on the 2014-2020 period and those publications that specifically deal with ICSR. Figure 4 shows a preliminary overview distributing the publications identified by their field of research, considering that the same publication could be considered in more than one category. As can be seen, management and business are the main areas in which ICSR is being studied and analyzed. In this recent period, we can distinguish the first stage of incubation of the term ICSR, and the second of consolidation, which continues to date.
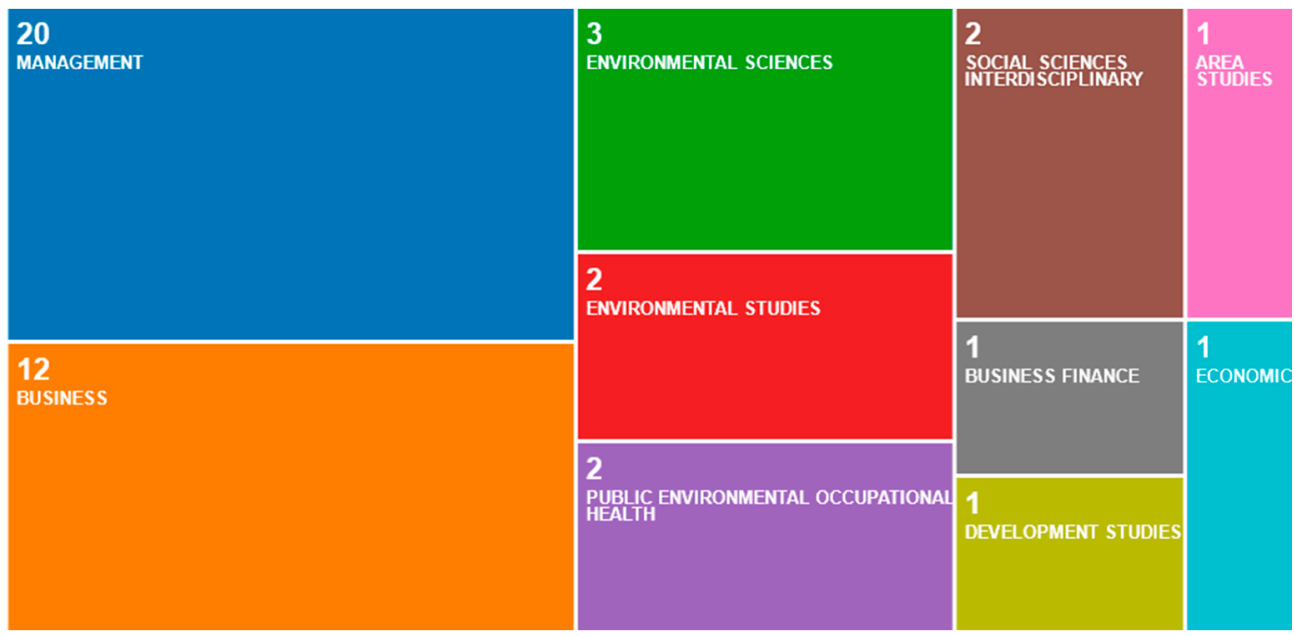

Figure 4. Classification of ICSR-focused publications included in the WoS database, according to their general field of research (2014-2020).

\subsection{Research Timelines and Hot Topics}

\subsubsection{The Incubation of the Term ICSR as a Research Topic}

In an early incubation phase, which took place between 2014 and 2018, a minimum number (testimonial) of papers containing the term ICSR was published and included 
in the WoS database. During this period, it is noteworthy that in several contributions, CSR appears as the main focus of research, while HRM is considered a component of CSR, either as an antecedent (that is, workers-HRM-develop CSR practices, as in Fenwick and Bierema [51]) or as a subset (i.e., HRM facilitates or enables CSR practices, as in the case of other factors, for example in Chen et al. [52]).

However, in some other contributions, CSR is considered a component of HRM, i.e., either enabling responsible HRM (e.g., Bhattacharya et al. [53]) or effective HRM (e.g., Deakin and Hobbs [54]). In these cases, which can be considered as usual as the previous ones in this first evolutionary stage, HRM constitutes the main focus of research.

As an alternative, what becomes progressively more frequent as this stage progresses is seeing CSR and HRM as mutually dependent topics, either as parallel (as previously, e.g., in Smith and Langford [55]) or interactive or overlapping (e.g., Westermann-Behaylo et al. [56]). Under this approach, both issues are considered the focus of the research. Specifically, Jamali et al. [57] defended a theoretical model of CSR-HRM co-creation, arguing that ICSR contributes to the creation of corporate shared value as proposed by Porter and Kramer in 2011 [58], subsequently improving competitiveness and productivity [59].

Regarding the term ICSR, it is used to examine employee behavior in the workplace and appears to be positively related to job satisfaction and employee engagement $[17,23,60]$. In addition to the definition of four dimensions in ICSR practice (workplace health and safety, organizational justice and fairness, employee training and development, and worklife balance) [61], other dimensions related to women's labor practices and human rights have been explored [62].

Although the ICSR concept has mainly arisen in developed capitalist economies, some contributions have analyzed how it was adopted in other contexts, such as in China, taking into account the specific practices of the ISO26000 framework [63]. ICSR has also been considered in a wide range of organizations, either focusing the attention, for example, on small and medium-sized enterprises (SMEs) $[23,61,64]$, studying the progress of ICSR on the foundations from the point of view of the balance between power and gender [65], analyzing ICSR in organizations belonging to public administration [25], or reviewing the situation in social economy companies [66].

3.5.2. Consolidation of the Research on ICSR: Work Engagement, Employee Well-Being, and Sustainability

The second and current evolutionary stage of ICSR research can be considered a phase of reinforcement or a strengthening phase, with continuous (and rapid) growth starting in 2019 and continuing into 2020 and 2021 (as well as being foreseeable that it will continue in the future). Different authors (such as Syed et al. [67], and Ostos and Hamann [68]) have confirmed the multidimensional structure of the CSR construct, recognizing ICSR as one of the main axes.

Work engagement and employee well-being are the hot topics or central research issues. Employee perceptions of ICSR, organizational pride, and perceived organizational support have been shown to impact work engagement [69]. At the same time, the benefits of obtaining an ICSR quality credential (such as SA8000, an auditable certification standard that indicates that a company goes beyond compliance standards to accommodate the well-being of its employees) have been demonstrated [40]. In the area of organizational commitment, it has been analyzed how motivations could promote the affective commitment of employees, which could translate into effective HRM policies [70], or it has been shown that ethical leadership is related to the perceptions of employees about ICSR, which, in turn, are related to organizational deviance through organizational commitment [37].

However, new issues are addressed that confirm the consolidation of ICSR as a research topic. In this sense, the relationship between ICSR and organizational creativity has been verified, emphasizing the importance of these findings for the case of SMEs in developing countries, since they often face difficulties in the implementation of external CSR due to resource limitations [71]. Simultaneously, ICSR-oriented governance mecha- 
nisms have been identified, such as board independence, the presence of a sustainability committee, and social performance-related incentives for managers [72].

ICSR has also been studied in non-business settings, and the factors in the ICSR environment are influenced by each of the components of the local social responsibility environment [73]. A positive relationship was also found between employee perceptions of ICSR and the prosocial and proactive behavior of individuals [74]. Specifically, the influence of ICSR on employee engagement in higher education institutions [75] and local public administrations [76] was analyzed.

Some of the latest publications included in the WoS database also focused on considering the role of ICSR regarding hot topics such as green supply chain management and its positive impact on company performance, and the capability to analyze big data, thanks to responsible management practices towards employees [77]. Other examples include research on how employees respond to ICSR practices and contribute to company performance through employee intrapreneurial behavior [41], or the consideration of how organizational culture influences ICSR practices and their impact on the level of happiness of employees [13]. A recent analysis on ICSR disclosure under the impact of the COVID-19 pandemic [78] is also noteworthy.

In summary, Figure 5 shows the network created with the selected codes, categories and relationships analyzed, in which we can observe the visual information provided by the data.

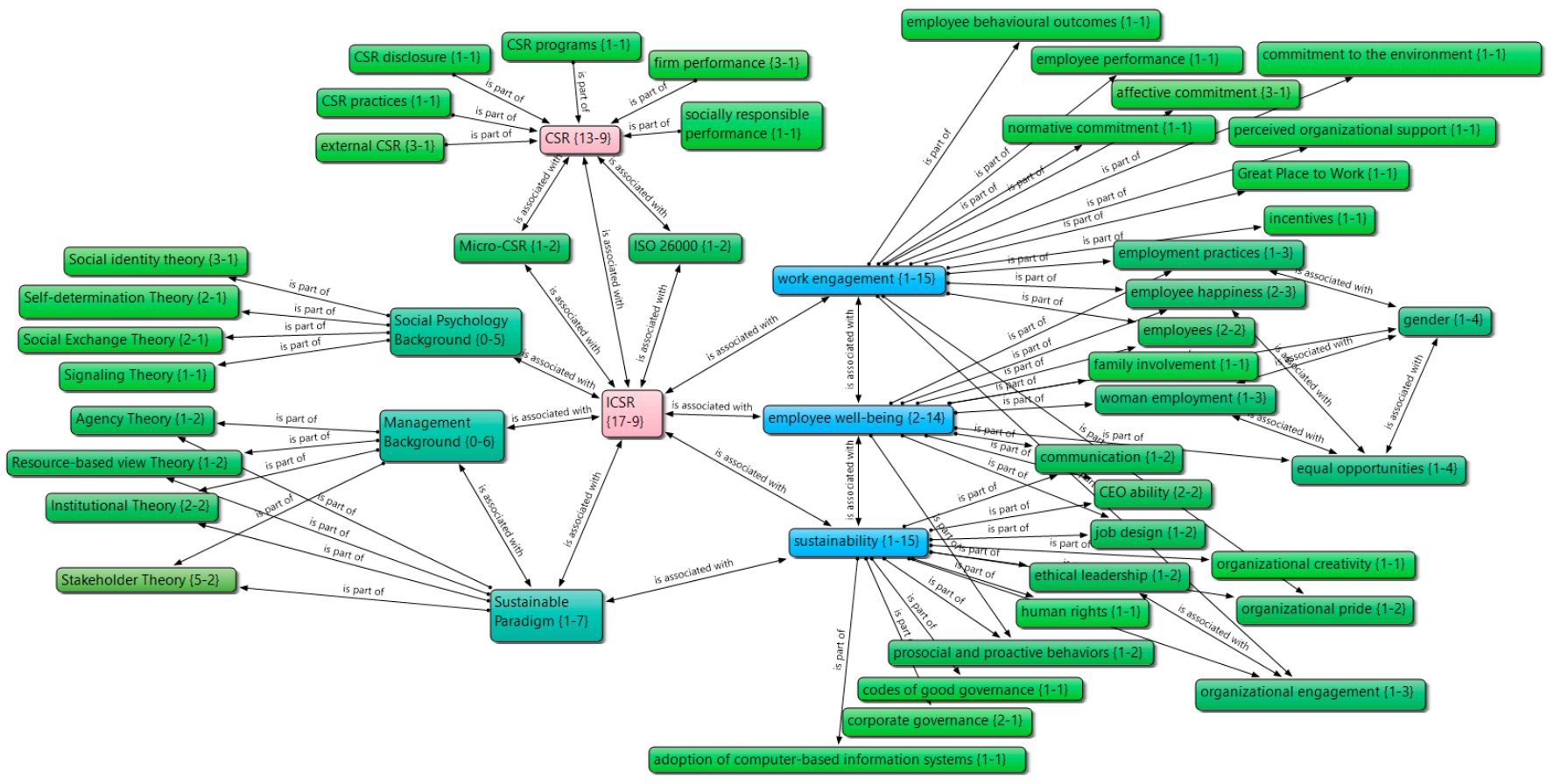

Figure 5. Research network on the topic of ICSR.

\section{Discussion}

Nowadays, the ICSR faces different challenges from a competitive and global point of view where the UN SDGs appear as a mandatory reference. Figure 6 shows the background and the evolution of ICSR presented before, and the research agenda for the near future. 


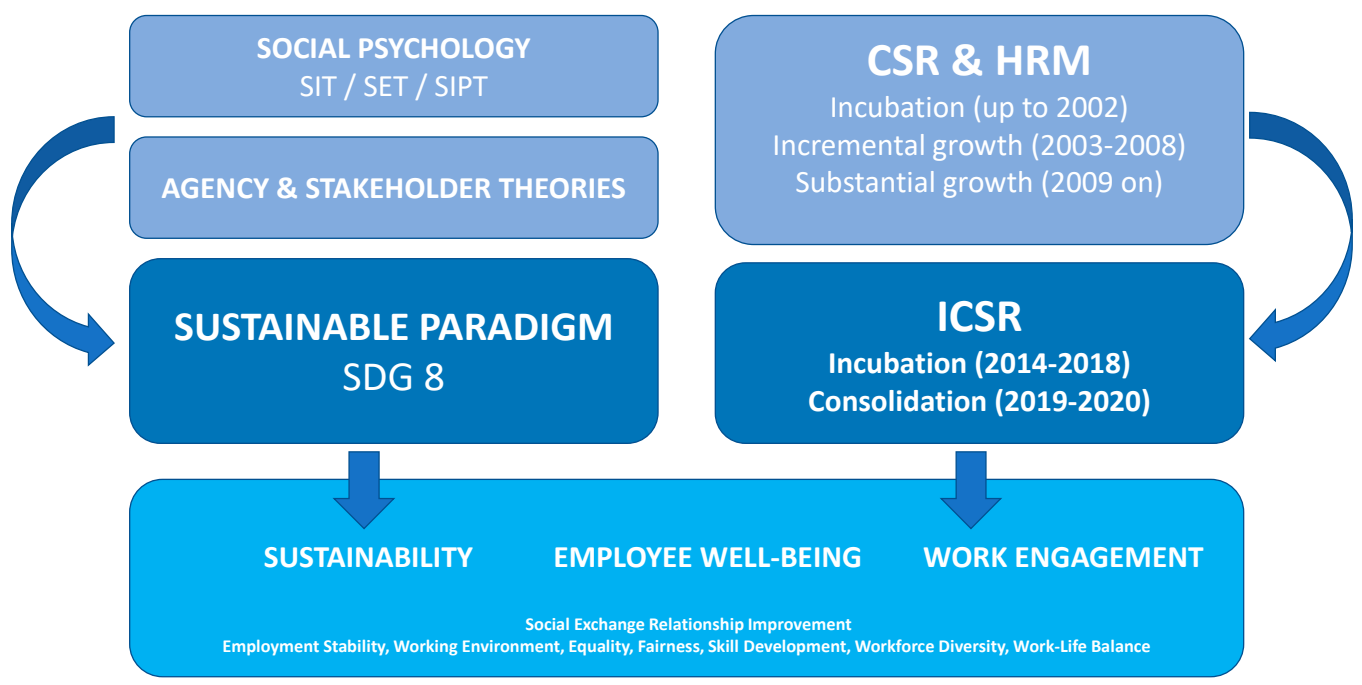

Figure 6. Background, evolution, and research agenda of ICSR.

Among these goals, SDG 8 appears to be especially relevant: "promote sustained, inclusive, and sustainable economic growth, full and productive employment, and decent work for all". In this approach, "decent" and "sustainable" work is understood as that which provides a fair income, safety in the workplace, and social protection to families, thus offering better prospects for personal development and favoring social integration. All people should have equal opportunities in the workplace and governments can work to build dynamic, sustainable, innovative, and people-centered economies, specifically promoting youth employment and the economic empowerment of women, as well as decent work for all, as the continuing lack of decent work opportunities, scarce investment, and low consumption erode the basic social contract that underlies democratic societies, i.e., that we should all benefit from progress. In this regard, there is some background on the topic of ICSR. For example, Farooq et al. [47] evaluated the criticisms and challenges of ICSR caused by the adoption of computer-based information systems by companies.

The International Labour Organization (ILO), as a specialized agency of the UN, has also endorsed SDG 8 and its goals, under its motto of advancing social justice, promoting decent work [79]. Such endorsement reached even greater emphasis after the virtual World Summit on COVID-19 and the World of Work which was held 1-9 July 2020 to build a better future in terms of employment after the coronavirus crisis. At these events, several strategies to solve the vulnerabilities revealed by the virus outbreak were discussed. In particular, the lack of social protection, informal economy, inequality, and climate change, must be addressed [80].

It should also be noted that during the ILO World Summit in July 2020, several proposed strategies were discussed to amend concrete vulnerabilities in the world of work that, although already pre-existing, have been highlighted as a result of the pandemic. In particular: (i) the needs of people who carry out their work without social protection or in the informal economy; (ii) the promotion of full and productive employment and sustainable businesses; (iii) the adoption of measures aimed at guaranteeing that the reduction in poverty, the promotion of equality and the fight against climate change are essential elements of the recovery process; and (iv) the measures that the international community can take to promote compliance with the UN 2030 Agenda for Sustainable Development.

In addition to SDG 8, ICSR is also related to other SDGs such as SDG 5, to "achieve gender equality and empower all women and girls", and SDG 10, "reduce inequality within and among countries", that is, ensuring no one is left behind. In the labor sphere, the impacts of COVID-19 are exacerbated for women [81] and ICSR could serve to mitigate these effects by seeking gender equality and women's rights, and recognizing that diversity 
is a source of innovation, promoting board gender diversity [82] or acknowledging that it is good for company employees to belong to a wide variety of cultures and ethnicities [83]. ICSR also has an impact on SDG 3 by promoting healthy lifestyles and combating premature mortality by increasing awareness about diseases and health risks among employees [84,85]; or on SDG 4, by promoting opportunities for inclusive and equitable lifelong learning for all employees, both internally or in partnership with schools or universities [86,87].

In summary, the research field that links CSR and HRM, and recently focused on ICSR, has begun to become aware of sustainability, employee well-being, and work commitment as specific topics aligned with the SDGs thanks to pioneer studies about issues as the improvement of the social exchange relationships, employment stability, work environment, equality, fairness, skill development, workforce diversity or work-life balance $[16,37,38,47,88-92]$.

Finally, it is evident from all the above that there have been — and there are-many reflections that have taken place at the international level about the future of work and what should be, in logical consequence, the evolution of ICSR and sustainability. Furthermore, as a result of these reflections, we now find ourselves with a wide catalog of challenges that academic research will have to face. We must not forget that academia used to be in some way "daughter of its time" over the years, and it has recently been adapting to the requirements of a model of economic development based on large-scale production, consumerism, and profit maximization, which, in the vast majority of cases, was detrimental to the interests of the worker and social conquests that had taken many decades to achieve.

\section{Conclusions}

Although the ICSR concept is relatively new, there is a substantial research background in the fields of CSR and HSR, respectively. ICSR theoretical paradigms stem from a combination of social psychology and stakeholder theories to converge on the current sustainable paradigm. Systematic bibliometric analysis and complementary content analysis reveal the consolidation of the term ICSR in the last two years and the connection with sustainability, especially with UN SDG 8. A responsible organization will always consider the internal side of CSR and focus on ICSR prioritizing the social well-being of employees. We believe that very soon companies will be directly involved in the SDG agenda through ICSR.

To conclude, it is necessary to present the limitations and implications for future research. According to the most recent contributions on the topic [92-94], there are several challenges to the ICSR research agenda, such as job stability, work environment, skills development, workforce diversity, and work-life balance, the improvement of social exchange relationships and employee engagement. In short, a promising future emerges for ICSR and internal sustainability. However, we want to highlight the limitations of the study as opportunities to continue deepening the understanding of ICSR as a specific area of research in management between CSR and HRM.

In this sense, and in the first place, it would be interesting to expand the study, on the one hand, using other databases such as SCOPUS and even Google Scholar, because both are being considered in other bibliometric studies in the field of management, and on the other hand, using other types of documents such as doctoral dissertations or papers presented at prestigious scientific conferences. It must be taken into account that, when a topic is innovative, as is the case of ICSR, advances usually appear in these documents before being published in journals. Second, this research could be complemented with other studies, both quantitative and qualitative, deepening the practice of ICSR by companies, to better reflect the evolution of the topic in the business field.

Author Contributions: Conceptualization, M.I.S.-H., J.L.V.-B., M.P.G.-M. and A.L.-C.; methodology, M.I.S.-H. and J.L.V.-B.; writing—original draft preparation, M.I.S.-H.; writing—review and editing, M.I.S.-H., J.L.V.-B., M.P.G.-M. and A.L.-C. All authors have read and agreed to the published version of the manuscript. 
Funding: This research was funded by the Regional Government (Junta de Extremadura and the European Union (FEDER), grant number GR18027.

Institutional Review Board Statement: Not applicable.

Informed Consent Statement: Not applicable.

Data Availability Statement: Not applicable.

Conflicts of Interest: The authors declare no conflict of interest.

\section{References}

1. World Commission on Environment and Development (WCED). Our Common Future; Oxford University Press: Oxford, UK, 1987.

2. United Nations (UN). Transforming Our World: The 2030 Agenda for Sustainable Development. 2015. Available online: https: / / www.un.org (accessed on 18 May 2021).

3. Elkington, J. Cannibals with Forks: The TBL of the 21st Century Business; Capstone: Oxford, UK, 1997.

4. Sánchez-Hernández, M.I.; Gallardo-Vázquez, D.; Barcik, A.; Dziwiński, P. The effect of the internal side of social responsibility on firm competitive success in the business services industry. Sustainability 2016, 8, 179. [CrossRef]

5. Sánchez-Hernández, M.I.; Grayson, D. Internal marketing for engaging employees on the corporate responsibility journey. Intang. Cap. 2012, 8, 275-307. [CrossRef]

6. Vázquez-Burguete, J.L.; López-Aza, C.; Lanero-Carrizo, A. Responsible human resources management in the university-A view of Spanish students. Hum. Resour. Manag. Ergon. 2014, VIII, 118-128.

7. De Stefano, F.; Bagdadli, S.; Camuffo, A. The HR role in corporate social responsibility and sustainability: A boundary-shifting literature review. Hum. Resour. Manag. 2018, 57, 549-566. [CrossRef]

8. Pérez, S.; Fernández-Salinero, S.; Topa, G. Sustainability in organizations: Perceptions of Corporate Social Responsibility and Spanish employees' attitudes and behaviors. Sustainability 2018, 10, 3423. [CrossRef]

9. Vázquez-Burguete, J.L.; Gutiérrez-Rodríguez, P.; García-Miguélez, M.P. Chance or necessity for applying internal marketing in public sector? Some evidences from local Spanish administrations. In Marketing in Dynamic Environments: Contemporary Research Advances; Veloutsou, C., Papadopoulos, N., Eds.; Athens Institute for Education and Research: Athens, Greece, 2008 ; pp. 381-392.

10. Grayson, D.; Sánchez-Hernández, M.I. Using Internal Marketing to Engage Employees in Corporate Responsibility; Working Paper Series; Doughty Center for Corporate Responsibility: Crandfield, UK, 2010.

11. Vázquez-Burguete, J.L.; Lanero-Carrizo, A.; García-Miguélez, M.P. Expectations of responsible human resources management in three institutional contexts. A survey study in Spain. Hum. Resour. Manag. Ergon. 2013, VII, 115-127.

12. Sánchez-Hernández, M.I.; Vázquez-Burguete, J.L.; García-Miguélez, M.P. New tools fostering human potential through internal social responsibility. Hum. Resour. Manag. Ergon. 2016, X, 86-96.

13. Sánchez-Hernández, M.I.; Stankevičiūtè, Ž.; Robina-Ramírez, R.; Díaz-Caro, C. Responsible job design based on the Internal Social Responsibility of local governments. Int. J. Environ. Res. Public Health 2020, 17, 3994. [CrossRef] [PubMed]

14. Pfeffer, J. Building sustainable organizations: The human factor. Acad. Manag. Perspect. 2010, 24, 34-45.

15. Ardichvili, A. The role of HRD in CSR, sustainability, and ethics: A relational model. Hum. Resour. Dev. Rev. 2013, 12, 456-473. [CrossRef]

16. Mory, L.; Wirtz, B.W.; Göttel, V. Factors of internal corporate social responsibility and the effect on organizational commitment. Int. J. Hum. Resour. Manag. 2016, 27, 1393-1425. [CrossRef]

17. Mory, L.; Wirtz, B.W.; Göttel, V. Corporate social responsibility: The organizational view. J. Manag. Gov. 2017, 21, 145-179. [CrossRef]

18. Gong, R.; Xue, J.; Zhao, L.; Zolotova, O.; Ji, X.; Xu, Y. A bibliometric analysis of green supply chain management based on the Web of Science (WOS) platform. Sustainability 2019, 11, 3459. [CrossRef]

19. Tranfield, D.; Denyer, D.; Smart, P. Towards a methodology for developing evidence-informed management knowledge by means of systematic review. Br. J. Manag. 2003, 14, 207-222. [CrossRef]

20. Aguinis, H.; Glavas, A. What we know and don't know about corporate social responsibility: A review and research agenda. J. Manag. 2012, 38, 932-968. [CrossRef]

21. Turban, D.B.; Greening, D.W. Corporate social performance and organizational attractiveness to prospective employees. Acad. Manag. J. 1996, 40, 658-672.

22. Lee, E.M.; Park, S.Y.; Lee, H.J. Employee perception of CSR activities: Its antecedents and consequences. J. Bus. Res. 2013, 66, 1716-1724. [CrossRef]

23. Voegtlin, C.; Greenwood, M. Corporate social responsibility and human resource management: A systematic review and conceptual analysis. Hum. Resour. Manag. Rev. 2016, 26, 181-197. [CrossRef]

24. Low, M.P. Internal corporate social responsibility: An overview. Aust. J. Basic Appl. Sci. 2014, 8, 18-29.

25. Low, M.P.; Ong, S.F.; Tan, P.M. Positioning ethics and social responsibility as a strategic tool in employees' affective commitment. Ann. Soc. Responsib. 2017, 3, 2-22. [CrossRef]

26. Tajfel, H. The exit of social mobility and the voice of social change. Soc. Sci. Inf. 1975, 14, 101-118. [CrossRef] 
27. Turner, J.C.; Oakes, P.J. The significance of the social identity concept for social psychology with reference to individualism, interactionism and social influence. Br. J. Soc. Psychol. 1986, 25, 237-252. [CrossRef]

28. Hogg, M.A.; Williams, K.D. From I to We: Social identity and the collective self. Group Dyn. Theory Res. Pract. 2000, 4, 81-97. [CrossRef]

29. Mael, F.; Ashforth, B.E. Alumni and their alma mater: A partial test of the reformulated model of organizational identification. J. Organ. Behav. 1992, 13, 103-123. [CrossRef]

30. Kim, J.; Song, H.; Lee, C.K. Effects of corporate social responsibility and internal marketing on organizational commitment and turnover intentions. Int. J. Hosp. Manag. 2016, 55, 25-32. [CrossRef]

31. Gond, J.P.; El Akremi, A.; Swaen, V.; Babu, N. The psychological micro foundations of corporate social responsibility: A person-centric systematic review. J. Organ. Behav. 2017, 38, 225-246. [CrossRef]

32. Kim, J.; Milliman, J.; Lucas, A. Effects of CSR on employee retention via identification and quality-of-work-life. Int. J. Contemp. Hosp. Manag. 2020, 32, 1163-1179. [CrossRef]

33. Homans, G.C. Social Behavior: Its Elementary Forms; Harcourt, Brace \& World: New York, NY, USA, 1961.

34. Blau, P.M. Exchange and Power in Social Life; Wiley: New York, NY, USA, 1964.

35. Emerson, R. Toward a theory of value in social exchange. In Social Exchange Theory; Cook, K.S., Ed.; Sage: Newbury Park, CA, USA, 1987; pp. 11-58.

36. Bos-Nehles, A.C.; Meijerink, J.G. HRM implementation by multiple HRM actors: A social exchange perspective. Int. J. Hum. Resour. Manag. 2018, 29, 3068-3092. [CrossRef]

37. Salancik, G.; Pfeffer, J. An examination of need-satisfaction theories of job attitudes. Adm. Sci. Q. 1977, 23, 521-540.

38. Zoogah, D.B. The dynamics of Green HRM behaviors: A cognitive social information processing approach. Ger. J. Hum. Resour. Manag. 2011, 25, 117-139. [CrossRef]

39. Mostafa, A.M.S.; Shen, J. Ethical leadership, internal CSR, organisational engagement and organisational workplace deviance. In Evidence-Based HRM: A Global Forum for Empirical Scholarship; Emerald Publishing Limited: Bingley, UK, 2019.

40. Lee, Y. Linking internal CSR with the positive communicative behaviors of employees: The role of social exchange relationships and employee engagement. Soc. Responsib. J. 2021. [CrossRef]

41. Spence, A.M. Market Signaling, Information Transfer in Hiring and Related Processes; Harvard University Press: Cambridge, MS, USA, 1974.

42. Jamali, D.; Samara, G.; Zollo, L.; Ciappei, C. Is internal CSR really less impactful in individualist and masculine Cultures? A multilevel approach. Manag. Decis. 2020, 58, 362-375. [CrossRef]

43. Luu, D.T. The effect of internal corporate social responsibility practices on pharmaceutical firm's performance through employee intrapreneurial behaviour. J. Organ. Chang. Manag. 2020, 33, 1375-1400. [CrossRef]

44. Bae, S.M.; Masud, M.A.K.; Kim, J.D. A Cross-Country Investigation of Corporate Governance and Corporate Sustainability Disclosure: A Signaling Theory Perspective. Sustainability 2018, 10, 2611. [CrossRef]

45. Freeman, R.E. Strategic Management: A Stakeholder Perspective; Pitman: Boston, MA, USA, 1984.

46. Donaldson, T.; Preston, L.E. The Stakeholder Theory of the Corporation: Concepts, Evidence, and Implications. Acad. Manag. Rev. 1995, 20, 65-91. [CrossRef]

47. Perrini, F. Building a European portrait of corporate social responsibility reporting. Eur. Manag. J. 2005, 23, 611-627. [CrossRef]

48. Anderson, N.; Costa, A.C.; Salgado, J.F. Sustainability and industrial, work, and organizational psychology: Globalization, contribution, and psychological sustainability. Ind. Organ. Psychol. 2012, 5, 487. [CrossRef]

49. Farooq, Q.; Fu, P.; Ahmad, S.; Zhang, Y.; Hao, Y. Assessing human factor in the adoption of computer-based information systems as the internal corporate social responsibility. Sage Open 2019, 9, 1-11. [CrossRef]

50. Gagné, M.; Deci, E.L. Self-determination theory and work motivation. J. Organ. Behav. 2005, 26, 331-362. [CrossRef]

51. Dupret, K.; Pultz, S. Hard/heart worker: Work intensification in purpose-driven organizations. Qual. Res. Organ. Manag. Int. J. 2021. [CrossRef]

52. Hristov, I.; Chirico, A. The Role of Sustainability Key Performance Indicators (KPIs) in Implementing Sustainable Strategies. Sustainability 2019, 11, 5742. [CrossRef]

53. Fenwick, T.; Bierema, L. Corporate social responsibility: Issues for human resource development professionals. Int. J. Train. Dev. 2008, 12, 24-35. [CrossRef]

54. Chen, J.C.; Patten, D.M.; Roberts, R.W. Corporate charitable contributions: A corporate social performance or legitimacy strategy? J. Bus. Ethics 2008, 82, 131-144. [CrossRef]

55. Bhattacharya, C.B.; Sen, S.; Korschun, D. Using corporate social responsibility to win the war for talent. Sloan Manag. Rev. 2008, $49,37-44$.

56. Deakin, S.; Hobbs, R. False dawn for CSR? Shifts in regulatory policy and the response of the corporate and financial sectors in Britain. Corp. Gov. Int. Rev. 2007, 15, 68-76. [CrossRef]

57. Smith, V.; Langford, P. Responsible or redundant? Engaging the workforce through corporate social responsibility. Aust. J. Manag. 2011, 36, 425-447. [CrossRef]

58. Westermann-Behaylo, M.; Berman, S.L.; Van Buren, H.J., III. The influence of institutional logics on corporate responsibility toward employees. Bus. Soc. 2014, 53, 714-746. [CrossRef] 
59. Jamali, D.R.; El Dirani, A.M.; Harwood, I.A. Exploring human resource management roles in corporate social responsibility: The CSR-HRM co-creation model. Bus. Ethics A Eur. Rev. 2015, 24, 125-143. [CrossRef]

60. Porter, M.; Kramer, M. Creating shared value. Harv. Bus. Rev. 2011, 89, 62-77.

61. De Freitas Brandão, I.; Diógenes, A.S.M.; de Abreu, M.C.S. Value allocation to stakeholder employees and its effect on the competitiveness of the banking sector. Rev. Bus. Manag. 2017, 19, 161-179. [CrossRef]

62. Terrero-De La Rosa, A.; Santiago-Ortega, R.; Medina-Rivera, Z.; Berrios-Lugo, J. Corporate social responsibility practices and programs as a key strategic element in organizational performance. In Corporate Social Responsibility and Corporate Governance; Emerald Publishing Limited: Bingley, UK, 2017.

63. Papasolomou, I. The Practice of Internal Corporate Social Responsibility in SMEs in Cyprus. In Corporate Social Responsibility in Times of Crisis; Springer: Cham, Switzerland, 2017.

64. Perdana, K.; Mardiana, N. How managers perceive internal corporate social responsibility: An empirical study of indonesian women's employment. In Redefining Corporate Social Responsibility; Emerald Publishing Limited: Bingley, UK, 2018.

65. Zhu, Q.; Zhang, Q. Evaluating practices and drivers of corporate social responsibility: The Chinese context. J. Clean. Prod. 2015, 100, 315-324. [CrossRef]

66. Pérez-Carrillo, E.F.; Rodríguez-Silva, T. Responsabilidad social de las fundaciones, y el género en sus patronatos. HOLOS 2016, 32, 414-431.

67. Vázquez, J.L.; Lanero, A. Citizens' perceptions on social responsibility in public administration organizations: A case study on Spain. Transylv. Rev. Adm. Sci. 2016, 12, 166-183.

68. Sajardo-Moreno, A.; Chaves-Sajardo, R.J. Social responsibility in social economy companies: A comparative analysis of the productive fabric of the Valencian Community. Revesco-Rev. Estud. Coop. 2017, 125, 213-242.

69. Syed, A.; Shanmugam, M. Nomological validation of Villa Castaño's socially responsible consumption scale. Int. Rev. Public Nonprofit Mark. 2020, 17, 509-526. [CrossRef]

70. Ostos, J.; Hamann, A. Corporate social responsibility and financial performance in the best companies to work in an emerging market. Rev. Univ. Zulia 2020, 11, 160-181.

71. Jia, Y.; Yan, J.; Liu, T.; Huang, J. How does internal and external CSR affect employees' work engagement? Exploring multiple mediation mechanisms and boundary conditions. Int. J. Environ. Res. Public Health 2019, 16, 2476. [CrossRef]

72. Dung, L.T. Impact of Internal CSR Perception on Affective Organisational Commitment among Bank Employees. Asian Acad. Manag. J. 2020, 25, 23-50.

73. Ngoc, N.; Tuan, N.; Takahashi, Y. Internal corporate social responsibility and organizational creativity: An empirical study of Vietnamese small and medium-sized enterprises. Intang. Cap. 2019, 15, 208-223.

74. García-Sánchez, I.M.; Hussain, N.; Martínez-Ferrero, J. An empirical analysis of the complementarities and substitutions between effects of CEO ability and corporate governance on socially responsible performance. J. Clean. Prod. 2019, 215, 1288-1300. [CrossRef]

75. Sirenko, N.M.; Lunkina, T.I.; Burkovskaya, A.V. Institutional Providing of Local Social Responsibility in Agrarian Sector of the Economy. Financ. Credit Act. Probl. Theory Pract. 2020, 1, 536-544.

76. Hur, W.M.; Moon, T.W.; Choi, W.H. When are internal and external corporate social responsibility initiatives amplified? Employee engagement in corporate social responsibility initiatives on prosocial and proactive behaviors. Corp. Soc. Responsib. Environ. Manag. 2019, 26, 849-858. [CrossRef]

77. Peng, L.M. The divergent influence of social responsibility on employee engagement through the lens of marital status: Evidence from higher education institutions. Rev. Bras. Gestão Negócios 2020, 22, 205-231. [CrossRef]

78. Wang, C.; Zhang, Q.; Zhang, W. Corporate social responsibility, Green supply chain management and firm performance: The moderating role of big-data analytics capability. Res. Transp. Bus. Manag. 2020, 37, 100557. [CrossRef]

79. Espasandín-Bustelo, F.; Ganaza-Vargas, J.; Diaz-Carrion, R. Employee happiness and corporate social responsibility: The role of organizational culture. Empl. Relat. Int. J. 2020, 43, 609-629. [CrossRef]

80. Liu, F.; Meng, L.; Zhao, Y.; Duan, S. The influence of the corporate social responsibility disclosures on consumer brand attitudes under the impact of COVID-19. Front. Bus. Res. China 2020, 14, 1-22. [CrossRef]

81. International Labour Organization (ILO). Institutional Website. Available online: https://www.ilo.org/global/lang--en/index. htm (accessed on 15 April 2021).

82. International Labour Organization (ILO). COVID-19 and the World of Work. Available online: https:/ /global-summit.ilo.org/ en/event/constituents-day (accessed on 15 April 2021).

83. King, T.; Hewitt, B.; Crammond, B.; Sutherland, G.; Maheen, H.; Kavanagh, A. Reordering gender systems: Can COVID-19 lead to improved gender equality and health? Lancet 2020, 396, 80-81. [CrossRef]

84. Griffin, D.; Li, K.; Xu, T. Board gender diversity and corporate innovation: International evidence. J. Financ. Quant. Anal. 2021, 56, 123-154. [CrossRef]

85. Wang, J.; Cheng, G.H.L.; Chen, T.; Leung, K. Team creativity/innovation in culturally diverse teams: A meta-analysis. J. Organ. Behav. 2019, 40, 693-708. [CrossRef]

86. Mills, P.R.; Kessler, R.C.; Cooper, J.; Sullivan, S. Impact of a health promotion program on employee health risks and work productivity. Am. J. Health Promot. 2007, 22, 45-53. [CrossRef] 
87. Buenadicha-Mateos, M.; Sánchez Hernández, M.I.; González-López, O.R.; Tato-Jiménez, J.L. Well-Being Lessons for Improving Charities' Online Recruitment. Front. Psychol. 2019, 10, 2582. [CrossRef]

88. Zhang, M.M.; Bartram, T.; McNeil, N.; Dowling, P.J. Towards a research agenda on the sustainable and socially responsible management of agency workers through a flexicurity model of HRM. J. Bus. Ethics 2015, 127, 513-523. [CrossRef]

89. Santana, M.; Cobo, M.J. What is the future of work? A science mapping analysis. Eur. Manag. J. 2020, 38, 846-862. [CrossRef]

90. Gutiérrez-Vargas, L.M.; Arenas-Cardona, H.A.; López-Gómez, M.S. The relationship between the use of work-life benefits and policies (WLBPs) and job satisfaction: The mediating role of the work-to-family conflict. Manag. Lett. 2020, 20, 75-86. [CrossRef]

91. Lee, Y. Bridging employee advocacy in anonymous social media and internal corporate social responsibility (CSR). Manag. Decis. 2021. early view. [CrossRef]

92. Pasamar, S. Why a strong work-life balance system is needed? Manag. Lett. 2020, 20, 99-107.

93. Sanusi, F.A.; Johl, S.K. A proposed framework for assessing the influence of internal corporate social responsibility belief on employee intention to job continuity. Corp. Soc. Responsib. Environ. Manag. 2020, 27, 2437-2449. [CrossRef]

94. Ye, Y.; Li, K. Impact of family involvement on internal and external corporate social responsibilities: Evidence from Chinese publicly listed firms. Corp. Soc. Responsib. Environ. Manag. 2021, 28, 352-365. [CrossRef] 